Published in: South European Society \& Politics, Special Ussue «Reinventing Democracy: grassroots movements in Portugal», Boaventura de Sousa Santos and João Arriscado Nunes (Eds.). Vol 9; Nº 2; Autumn 2004 (pp 253-283).

\title{
ELÍSIO ESTANQUE
}

\section{The Reinvention of Trade Unionism and the New Challenges of Emancipation: From Local Despotism to Global Mobilization}

\section{Introduction}

This essay analyzes a case study which needs to be presented in context. The impacts of neo-liberal trends of the world economy are polymorphic - multiple and changing in different regional, spatial and social contexts. Globalization itself is paradoxical, causing new forms of localisation, in which new opportunities for social inclusion combine with new forms of oppression and exclusion (Boyer and Hollingsworth, 1997; Santos, 1995 and 2000). There is an evident contrast between the apparent scope and strength of international capital, on the one side, and to the apparent limits and fragility of trade union movement, on the other. Of course, the strength of the first tends to debilitate the other. But the local effects are not uniform, depend on a complex of inter-reaction at work and within local civil society and offer different choices for the response of international trade union movements.

The approach taken in this work closely follows the proposals of Boaventura Sousa Santos in trying to go beyond sub-paradigmatic interpretations towards a paradigmatic stance capable of challenging hegemonic globalization by making counter-hegemonic tendencies and movements visible (Santos 1995b: 258 ff.; 2000: 70110). This framework suggests that globalization draws varied contrasts and connections within society, in its geographic, political, economic and cultural dimensions. In this process of reciprocal inter-action, 'globalization' is the counterpart of 'localization', and in which 'local sub-classes' are the counterpart of the 'global overclasses' (Lash, 1999). The analytic challenge for social science and critical theory is to illuminate such reciprocal inter-action and local alternatives which, in a fragmentary fashion, have begun to emerge in the present global context. This implies hearing the voices of the margin, shedding light on the micro examples that evidence differences, and contributing to their visibility as 'models of utopian realism' (Giddens, 1990). 
The case study analyzed in this essay - the trade union of the footwear industry in the industrial district of São João da Madeira (SJM) in Portugal - offers an example of resistance, where different forms of local connections between industry and community, between work and cultural activism, constitute a basis for a form of social struggle which can inform and may amplify networks of solidarity from the local to the international level. It is an example how countering the liberal utopia with a heterotopia of resistance can contain an emancipatory potential. In spite of all the disciplinary mechanisms and strong ideological constraints with which workers have to cope, the strategy followed by the trade union leadership shows how such experience on the margins of the system, can lead to new connections between trade unions, social movements, local associations, etc., and at the same time offer new forms of articulation between roots and options (Santos, 2000: 307).

Closely related with neoliberal trends of the global economy and also as a result of the collapse of Communist mythology, 'class unionism' is fragile and currently riven by countless problems. Not only have the working class struggles been 'cannibalized' by capitalism, the administrative structures of the main trade unions have also largely become instruments of state regulatory action. The trade unions themselves have also contributed to this process, by 'cannibalizing' the old proposals of revolutionary action. In the midst of all this, the conquests made by workers and by the traditional trade union movement have largely given way before the pressures of co-option, and have imperceptibly entered the dynamic of the system, becoming absorbed by the logic of regulation (Santos, 2000: 335). However, side by side with the discrediting of the 'old' worker- and national-based trade unionism, there have appeared signs of renewal, especially at the level of ideas and political debate, both in the academic sphere and in the trade union field, which point towards the emergence of a 'new' social trade union movement of global or international scope (Ashwin, 2000; Bezuidenhout, 1999; Moody, 1997).

Recent approaches by Peter Waterman are precisely in this direction. In order to reconceptualize the old trade union internationalism with a national/industrial/colonial basis so as to adapt it to the present capitalist era of global information networks, a new social trade unionism is necessary, founded upon a new labour internationalism. Its main features will have to involve democratic and pluralist strategies and struggles capable of linking the workers' problems to those of other social segments, movements 
and communities, ${ }^{1}$ within the framework of the construction of an ethics of international solidarity that “surpass[es] an 'export solidarity' model by practising 'international solidarity at home', combating the local causes/effects of international exploitation and repression” (Waterman, 2000). As we can see, these proposals are part of the theses about Portuguese trade unionism presented by Santos in 1995. He emphasizes the principle of solidarity as a necessary response to the growing reinforcement of local and transnational regulations, at the expense of national regulatory mechanisms. The construction of an active citizenship would imply the combination of a greater direct involvement of trade unionism in the space of production, namely through the reinforcement of the role of workers' committees, with a greater intervention outside the space of production by establishing connections with "other progressive social movements, consumer movements, feminist movements, and so on... the trade union movement's energies for protest should shift towards the articulation with these other movements" (Santos, 1995a: 135). This means that trade unionism, if it is to be reinvented, will have to open up to fields outside production and free itself from the national and sectorial format in which it is imprisoned. As José Manuel Pureza suggests, there are now two alternatives for the transforming and emancipatory intervention of trade unionism: either it remains enmeshed in national social pacts, or it rebuilds itself as a social movement dedicated to combating the logic of the internationalization of capital (Pureza, 2001).

While emancipation has been a somewhat paradoxical notion, the experiences of the life world, whether framed by the spheres of the community, production or household, may present themselves as fields of struggle between the contamination of the system and the contamination of emancipatory action. Experiences of struggle are always important life experiences, even when their material aims are not achieved, and their effects, particularly upon the reflective reconfiguration of individual or collective identifications, also affect the conditions of future action. Lived experience contains within itself elements of reflexivity that make up the cognitive involvement of the actors in emancipatory struggles. That is why leaders repeatedly exalt past struggles. Building

\footnotetext{
${ }^{1}$ Among other things, the new trade unionism proposed here requires that the struggle within the work force be linked to actions concerning the issue of wage labour; that demands for better wages and better working conditions be accompanied by more control over the production process, investments, new technologies, relocation, subcontracting, and education and training policies; that the struggle against authoritarian and technocratic methods of control be based on alliances with other non-union sectors, movements and communities; and that there be dialogue and cooperation with other forces and
} 
a patrimony of identity out of the memory of historical experience is a way of restoring collective dignity and opening up paths to the future. Even when the past was not satisfying, it is always preferable to reflect upon it and try to understand it than to allow it to sink into oblivion.

\section{From regulation to emancipation: between industry and community,}

\section{between the local and the global}

In the light of these concerns, I will seek to analyse the main processes and mechanisms of social regulation, as well as forms of resistance and moments of struggle and emancipatory rebellion, which, with all their contradictions and ambiguities, led to the shaping of the working class of the region of São João da Madeira (henceforth, SJM). The interpretation of these processes is based upon a double articulation: the connection between industry and community, and between the local and the global. These two dynamics obviously do not constitute separate realities, given that industry has asserted itself as the principal mediator between the local and the global, facilitating the penetration of local communities by external factors - namely the market at national and international levels. However, I take them as analytically distinct dimensions, since they operate on different scales and allow us to visualise the way this double logic has acted upon the socio-cultural complexity of the region. To a large extent, the processes of structuring of community identities and collective subjectivities of local actors take place within these two dimensions. As I will show, this explains the selection of the footwear workers' union (the most representative industrial sector of the region) as a privileged collective actor, since it has, at different times, been the main stimulus of resistance vis-à-vis the hegemonic logic exerted through those two articulations. Either of them, therefore, may constitute a model of regulation within the current dominant paradigm, while, at the same time, being susceptible to producing orientations and subjectivities of an emancipatory nature. This also justifies the importance given to the reconstruction of historical experience, which means attempting to carry out an operation "of archaeological excavation in the regulatory magma in order to recover the emancipatory flame, no matter how weak it might be” (Santos, 2000: 335). Therefore, it is based on the analysis of this double articulation that I will, firstly, describe the way in which the main social mechanisms were produced for the 
framing and domination of the workers in the region, and secondly, outline the present challenges, which continue to reveal the dialectical character of the conjugation of the new tendencies of hegemonic globalization and the new networks of emancipatory solidarity.

In the first articulation, industry worked as a determining factor in the reshaping of the territorialized community, restructuring it and adapting it to the logic of production and of the market, and managing it in such a way as to neutralize the formation of strong communities of resistance. This means that the economicist and individualistic perspective that supports capitalism was able to penetrate into worker collectivities more profoundly and efficiently than the collectivist socio-political perspective underlying trade union struggle. This is to say that it was mostly under the pressure of capital and not of labour (or class) that rural communities approached industry. However, this articulation was never static, but rather marked by multiple dynamics and forms of resistance, latent or explicit.

As has already been made clear, the perspective adopted here concerning the concept of community, namely when discussing its relation with industry, is to view it as a set of discursive constructions, often conflictive, which support the structuring of its identity. One must, then, avoid conceiving community in a merely territorial, substantive or static sense. Community is a dynamic socio-cultural process involving multiple struggles, discourses and identification dynamics, which oscillate between localized subordination, dependent on the demands of production, and the community in movement, which asserts its originality and demands recognition, dignity and expansion opportunities vis-à-vis the dominant powers. It is in this sense that we may be able to anticipate a new turn in the articulation between industry and community, which will allow the latter to impose forms of "cosmopolitan" pressure on the former in order to prevent the violation of rights and achieve new rights for workers and collectivities.

Of course this can only occur if the future social conditions in the labour market, as well as in the leadership structures of the trade union, favor the renewal of its collective action. For that, activist initiatives will have to combine workers' resistance from within companies with other forms of grassroots and local associations outside the sphere of industrial relations, in order to reinforce its capacity to intervene. Only by restructuring the role of the community will labour collectivities be able to restructure their leading role within enterprises. This means that the future of trade union action will cease to be supported primarily by “class” action, becoming an aggregation of local 
movements, whose struggles will be aimed not only at (and within) the company, but also, simultaneously, towards other social movements and state institutions, from the local to the transnational level (as I seek to show in the next section).

As regards the articulation between the global and the local, the impact of industrialization and the market dynamics established in the region over the years has resulted in the growing hegemony of a global logic over the local. It must be added, firstly, that such logic was, and still is, strongly intermediated by the national; and, secondly, that such overdetermination of the global was only effective to the extent that it was able to incorporate and co-opt significant elements of the local dynamic, harnessing them to the needs of industry (as I mentioned above) and thus maximizing their modelling effects. We are thus talking about forms of localized globalism (Santos, 1995b: 263) which, through diverse agents and frameworks, have prevented local cultures and worker collectivities from asserting themselves and extending their rights into wider spheres, moving from the local to the global by way of the national. At different times, it was the general interests of the economy, of state institutions and of global markets which most marked local identities and subjectivities, circumscribing them to the region or to fortress communities (Santos, 2000: 314). Although this articulation still involves the hegemony of the global over the local, it might also be inverted in the medium term. If this happens, it will entail the reinvention of trade unionism in the sector and the latter's capacity to introduce local elements, with their sociocultural specificities and dynamics, into its programmes of global struggle. If the footwear workers' union is able put into practice new forms of transnationalization and the project of enlargement of the international solidarity networks in which it participates, it may become the main mediator between the local and the global, in a counterhegemonic sense. In this way, trade union action and the local movements with which it seeks to ally itself would effectively function as brakes to the present logic of hegemonic globalization, counteracting it with a new logic of global solidarity promoted through new emancipatory dynamics and new coalitions and alliances, oriented towards the defence of the dignity of work and the recognition of the community.

The connection between industry and community: building authoritarian paternalism 
Despite the social and political importance of early working class movements in Portugal, their rather dispersed and fragile character in organizational terms is well known (Cabral, 1979; Tengarrinha, 1981). Beyond their dramatized discourse and even the emancipatory possibilities that they opened up for the Portuguese working class, these experiences introduced a working class language in Portugal. However, similarly to what happened in England in the first half of the 19th century, these movements were clearly marked by the logic of local communities, by a defensive and even conservative stance towards the threat of modern machinery and industry (Thompson, 1963; Hobsbawm, 1984; Jones, 1989).

It was by means of a similar process that, in this region, diverse sociocultural elements were transferred from the sphere of the household and domestic crafts to industry, particularly during the first stage of industrial and commercial growth in the final years of the 19th century. In the first phase, units of production multiplied, based on the same family matrix in which the traditional craft of shoemaking operated. Located in the household, and resorting to the help of their children and of apprentices hired through neighbourhood networks, masters only needed to create the conditions to respond to a growing number of orders. Even after the first manufacturing units were set up, most workers continued to produce from their homes, and, when they did eventually start to work in larger units, some of the tools belonged to the workers themselves, which clearly illustrates the persistence of the crafstman logic. Moreover, the implantation of companies already supplied with mechanized equipment did not immediately prevent production from continuing to depend largely on isolated producers, who resisted having to travel every day to the factory. Pressure for a greater concentration of the work force only came later, both from entrepreneurs, who were investing in mechanization, and from trade union activists, who saw that this provided better conditions for union action.

It might be said, therefore, that the first phase of expansion of the footwear industry essentially obeyed a patriarchal logic, which continued to shape the production demands and structuring processes of industrial relations, remaining under the strong influence of family ties. However, if the family was the first structural factor of mediation between the community and production, the strongest pole of structural power was gradually displaced as industry grew and market demands increased. It is known that the dynamics of family-rooted affinities and loyalties is still present in enterprises. Nevertheless, there has been a slow but persistent movement away from 
family rule to rule through the family; that is to say, with the gradual loss of family autonomy, the community also turned from being a bastion of resistance to a vehicle of domination (Burawoy, 1985).

As workshop production gradually lost its initial hegemony, the family logic and communities themselves gradually gave way to a new type of paternalism, of a neofeudal nature, by means of which entrepreneurial despotism extended its control mechanisms over the working class, through the family and the community. Such despotism conveyed mercantilist logic, whilst retaining its paternalistic dimension. Indeed, it could be said that this double logic, precisely because it was ambiguous, was able to impose framing mechanisms upon the community through the paternalistic dimension, in order to simultaneously exercise despotic power over the workers in the shop floor. Far from being linear, this process took on interesting contours, which demonstrate not only the reasons for its strength and efficacy, but also the way in which, to be effective according to the logic of regulatory modelling, it had to produce and assimilate emancipatory experiences.

It is important to point out that most of the entrepreneurs of SJM (even the wealthiest) had their social roots in the working class. Some had begun their activities with small units of production in the region, but those who contributed most at that time to the acceleration of the process of industrial modernization had accumulated most of their wealth through business in Brazil, which had been the main destination for migrants since the 19th century. Many employees saw in the entrepreneurs, from the smallest to the largest, successful examples of what could be achieved, in terms of upward social mobility, through dedication to hard work and productive discipline. A central nucleus of that recomposition was based on the defense of the productivist idea, which led to the development of SJM as "the Land of Labour," a formula still displayed on the local flag. The adaptation of the old community to the new mechanisms of regulation thus entailed the conversion of the traditional paternalism, which characterized the relationship between the local elites and the people, into a form of neo-paternalism between employers and employees. As the demands of the market and productivity grew stronger, paternalism gradually gave way to company despotism.

In this respect, it is also convenient to mention the repressive role of the Salazar regime, with its project of corporatism, which, from 1933, outlawed the old class-based unions and imposed corporatist trade unions, which brought together workers and employers in the same organization (including with mandatory affiliation for all the 
workers). All of this took place within a framework of strict authoritarian and ideological control, of conservative, rural and Catholic inspiration, which, until 1974, maintained the country in a situation of great socio-economic backwardness, with no political freedoms.

However, that process was always accompanied by a dialectic of conflict. Just as regulatory formulas sometimes took on the contours of emancipation, so emancipatory dynamics sometimes rose out of the official institutional framework. This happened, for instance, with the corporatist trade union created in 1933, which involved the cooptation of a new leader who was a sympathizer of communist ideals. ${ }^{2}$ The handcraft origins of shoemaking, and the proximity between workers and small employers within the same communitarian matrix also contributed to the creation of unusual alliances. The community's subjection to the hegemonic powers was achieved by means of a double control: repressive, disciplinary action, exercised mainly through the suppression of autonomous trade unionism and the disciplinary framing of workers within companies; and doctrinal and ideological action exercised by state and church institutions over worker and community associations (organized as free time organizations for workers).

Over the last four decades (mainly since the 1960s), there has been a diffuse growth of the industry from the town to the outskirts, to the most rural collectivities. This has permitted semi-wage workers to keep their connections with agriculture and with an innocuous religious and recreational associationalism. At the same time, the force of the market has become more overwhelming, injecting into the community a whole set of consumer references and codes that promote individualistic alienation and inhibit collective participation. Nevertheless, despite the neutralization or co-option of some of the struggles and acts of resistance of the past by the mechanisms of regulation, it should not be concluded that the community has lost all of its emancipatory potentialities. It is in this context that trade union action has been playing an essential role in recent decades.

\section{The potentialities of community-oriented trade unionism}

\footnotetext{
${ }^{2}$ Although he was officially subordinated to the structures of the Salazar regime, the National Trade Union of Footwear Workers of the District of Aveiro, this leader (António Carreirinha) used his position for approximately ten years as a legal cover for a whole clandestine activity, organizing and mobilizing footwear workers (which culminated in the August 1943 strike), a process set in motion by the local branch of the Portuguese Communist Party (PCP) to which he belonged.
} 
One of the main virtues of this union structure - the Trade Union of Workers in Footwear, Bags and Related Articles of the Districts of Aveiro and Coimbra - lies in the attention that it has given to grassroots work and to the proximity with the workers' collectivities, not only within companies, but also as regards the articulation with other associational and cultural activities. The very fact that the main leader of this trade union (M. Graça) since the late 1970s initiated his associational activity in the sphere of community-based cultural associationalism shows us that we have here a concept of trade unionism that is, in many ways, different from the traditional model in Portugal.

Workers' struggles in this region before April $251974^{3}$ only occasionally went as far as open contestation, as in the case of the 1943 strike, or the strike movements at the end of the 1960s in the metalworking sector (in the Oliva sewing-machine company). ${ }^{4}$ In the so-called "hot summer" of $1975,{ }^{5}$ when diverse anti-communist protests appeared throughout the country, SJM was one of the first places where the headquarters of left-wing parties were attacked and vandalized. These protests were associated with the conservative right and the sectors of the local workforce were undoubtedly dominated by the interests of employers ${ }^{6}$. In a scenario characterized by profound political and ideological divisions, it is not surprising that, alongside those events there were also various workers' protests, factory occupations, and a massive affiliation to trade unions in the region, ${ }^{7}$ as happened all over the country in the agitated years of 1974-1975. ${ }^{8}$ However, following the political about-turn which occurred in the

\footnotetext{
${ }^{3}$ This is a date of historical importance in Portugal, because it was on this day that the military coup led by a group of democratic officers of the Armed Forces (the Armed Forces Movement or MFA) overturned the previous Fascist regime and initiated the process of democratization in the country.

${ }^{4}$ Mention should be made of the movements supporting oppositional presidential candidates, such as, in 1948, Norton de Matos, and ten years later, Humberto Delgado. These situations represented two significant moments of political contestation during the repressive Salazar regime, but it would be excessive to consider them as movements of resistance to capitalism or industrial exploitation.

${ }^{5}$ The summer of 1975 (from March 11 to November 25) was thus named due the great conflicts that developed within Portuguese society, both between rival factions of the Armed Forces, and between different social sectors, political parties, trade unions and diverse popular movements, in a scenario of great political and ideological radicalism.

${ }^{6}$ Not only the employers but also significant segments of the local population were at that time particularly alarmed at the power that the revolutionary discourse and the role of the Portuguese Communist Party were achieving in Portuguese society.

${ }^{7}$ It should be noted that at the beginning of the 1980s trade union membership was at about $60 \%$.

${ }^{8}$ The Revolution of 1974, which marked the end of the fascist regime and the beginning of democracy, was also known symbolically as the Carnation Revolution. This was, first, because it was a peaceful change of regime, and the soldiers that took part in the movement did not need to use their firearms, since the forces loyal to Marcelo Caetano — the Prime Minister who succeeded Salazar in 1968 — surrendered to the MFA officers without any bloodshed. Second, because the people of Lisbon, who flocked into the streets of the city on that day to applaud the victorious soldiers, offered them red carnations to place in the barrels of their rifles, symbolizing the love of peace and freedom. This movement then spread to the main
} 
country at the end of $1975,{ }^{9}$ there was a period of reflux in popular and trade union mobilization (as mentioned before, never very strong in this region), which was favourable to the climate of persecution of activists within companies, or, in some cases, their co-optation into better-paying positions in exchange for the abandonment of trade union activity.

It was in this scenario that the new directorate of the footwear workers' union outlined a plan of action that was more suitable for the reality of this sector, under the influence of M. Graça. His trajectory deserves to be mentioned in a brief note. Although he was a working-class leader, Graça had become involved in associational activism and political intervention very early in his life, which explains the attention that the trade union has lately given to cultural intervention and to the establishment of alliances between the union and other associations and NGOs in different fields. It is precisely this effort to combine initiatives geared towards other community spheres, which, when closely articulated with intervention in companies, could become the main capacitating factor of emancipatory energies, enabling the union to oppose the regulatory logic to which the community has been subjected.

Various initiatives of this kind have been promoted, many of which reveal the same contradictory features that have marked the articulation between "new" and "old" social movements in Portugal (Santos, 1994). In this trade union, whose main leader, of working class background, demonstrated early on a particular interest in the cultural dimension, ${ }^{10}$ the ideological values of the radical left are combined with a refined pragmatic sense; its orientation appeals to popular participation, assuming the importance of dialogue and negotiation; and it advocates a combination of participatory

cities of the country, and helped to popularize (with the help of the mass media) the name "Carnation Revolution.”

${ }^{9}$ On November 25, 1975, there was a military counter-coup led by Ramalho Eanes (who later became President of the Republic), which sought to neutralize the growing power that the radical left (sectors which were directly or indirectly linked to or instrumentalized by the Portuguese Communist Party) had achieved in Portuguese society and in the military and state apparatus. Under the influence of a moderate wing of the Armed Forces (MFA) and with the active support of the Socialist Party (led by Mário Soares), the country entered a new period of progressive normalisation of institutions and of a lull in social and union struggles. This opened up the way for a project of liberal democracy compatible with the European model of society, which later culminated in the accession of Portugal to the European Community (the agreement was signed in 1986 by the then Prime Minister, Mário Soares).

${ }^{10}$ He began his activity in the cultural association ARCA - Cultural and Recreational Association of Oliveira de Azeméis, a few years after starting work in the sector, in the second half of the 1960s. 
and representative democracy. This is largely the result of the present leader's experiences in the revolutionary period following the 25 April 1974. ${ }^{11}$

I used to believe in immediate struggles, but I also defended-against many, who did not believe in them-legislative elections and representative democracy, because I thought (as I still do) that these things are not incompatible. It is possible to combine this with participatory democracy, with the intervention of the masses, of grassroots popular organizations. They are not at all incompatible. I believe that the people have the right to organize themselves into political parties and organizations. It is, in my opinion, a... sacred right! I am not a Catholic, but it is... sacred. Now, in specific cases, it is clear that I was always on the side of those who argued for popular participation, there's no doubt about that. (Trade union leader, SJM, July 2000)

These characteristics have clearly had a strong influence on the functioning of the trade union structure since the beginning of the 1980s, and this is undoubtedly related to the implantation and the levels of sympathy and support that it has achieved amongst workers of the sector. It was this concept of militancy that allowed the union to withstand a particularly difficult climate for the industry two decades ago:

There was great repression in companies and the trade union movement generally began to go into decline, didn't it?... So, many activists were fired...although the strike had a huge number of participants and lasted two weeks. That's why there was a cycle of dismissals afterwards. It was the period of greatest repression and lots of people got laid off, mostly activists, those that manned the pickets. At that time, there was a very brutal direct repression in the companies. Now it's subtler, isn't it? It was a "cleaning job," which lasted about four years, so a period of great backsliding. (Trade union leader, SJM, July 2000)

Given the difficulty of creating strong, organized and cohesive structures inside the companies, particularly in the small and medium-sized businesses that are predominant in the sector, trade union leaders travel daily to the gates of factories to hear what workers have to say and inform them of their rights. Faced with illegalities and the suppression of rights, the union responds by combining the discourse of indignation with legal action, with largely positive results for the workers. It exposes and protests against despotic attitudes or even acts of violence exercised by many proprietors over the workers, whilst trying to keep open channels for dialogue; it defends women's rights by denouncing discriminatory practices and making use of the legal channel; and in cases of child labour, it seeks to pressure the Inspecção Geral do Trabalho (General Inspection of Work) and launches media campaigns, which, since

\footnotetext{
${ }^{11}$ It should be pointed out that this trade union leader was doing his military service at that time and therefore represented the MFA in the resolution of various labour conflicts in the greater Lisbon area. This context, which was marked by "revolutionary" discourse and by the presence of strong but contradictory popular movements, was undoubtedly an important moment in the political education of this leader. Despite the experience he had already accumulated, his arguments for the articulation between
} 
the mid-1990s have had remarkable success; given the production logic based upon intensive labour and a cheap work force which prevails in the sector, the union seeks to ensure that workers' interests are protected, while at the same time participating in negotiations concerning reconversion programmes in larger companies.

Many repressive practices continue to prevail in the enterprises of the sector, ${ }^{12}$ but denunciation and resorting to the courts (with many cases resolved in favour of the workers) seem to be having a dissuasive effect upon employers. This clearly shows why this trade union can be taken as an exemplary case as regards the way in which it has managed to coherently combine the different components of its activity. In addition to its ability to carry out the traditional functions of trade unions - defending members, establishing a dialogue with social partners, and political activation (Rosanvallon, 1988) — this trade union has provided consistent proof of its efforts to ally the firm defence of emancipatory principles with a realistic sense of action, thus allowing it to achieve a fair balance between protest and negotiation.

For instance, despite the disciplinary power and despotic authoritarianism of the factory, workers have often succeeded in eluding this through multiple tactics of a subversive game (Estanque, 2000: $270 \mathrm{ff}$.). During the three months in which I worked and lived with the workers of one footwear factory, I witnessed many signs of how 'consent' is accompanied by forms of 'tacit resistance' that sought to undermine despotism and subvert structures of power. While recognizing the fragility of the classconsciousness of these workers, the restructuring of their collective identity in the factory has produced many forms of escapism and games that subvert the disciplinary power through collective daily practices (Linstead, 1985). The assembly line supervisor complained that the workers always tried to do things their own way and said that some

the trade union movement and the new social movements, as well as between local and global dimensions, have been fundamentally influenced by that period and that intense experience.

${ }^{12}$ A glance at the newspaper headlines reveals the repressive conditions in companies and some of the struggles that the union has faced: "Trade unionist stabbed by footwear entrepreneur" (Jornal de Notícias, 15/3/88); “'Security guards’ attack trade unionists in a factory in S. João da Madeira” (Jornal de Notícias, 20/7/90); "S. João da Madeira - Violence in the footwear strike” (Público, 1/9/93); "Workers prevent machines leaving factory in Arouca - Vigilance in the footwear industry" (Público, 28/10/95); "Workers from company in Arouca without wages - Factory closure leads to demonstration” (Jornal de Notícias, 27/9/95); "Worker suspended from footwear factory - Supreme Court overturns sanctions on union representative” (Público, 19/11/96); "Trial of alleged unionist attackers - to be or not to be the moral author, that is the question” (Público, 5/11/96); "Employer and 'security guards' condemned for aggression against trade unionists” (Jornal de Notícias, 15/11/96); “GNR [Republican National Guard] says it saw nothing - unionists 'sequestrated' by employer” (Jornal da Feira, 8/5/98); “'Basilius' Company in the defendant's chair - 'Let justice be done', says the union” ( $O$ Regional, 22/01/00); "Footwear employer condemned for sequestering trade unionists" (Jornal de Notícias, 25/3/00); 
of them were trying to "make my life a misery... and test me out to see how soft I was. And the more they felt I was soft on them, the more they took advantage... sometimes I pretended not to notice but I understood what was going on all right!” When I asked him why he shouted at the workers from a distance when they were, as he put it, "filing their nails” (meaning that they were chatting or slacking), he gave me the following explanation: "before, I used to go up to them and point out what they were doing and control things. But I began to realise that they just wanted to give me the runaround. When I went up to someone who was talking or fooling around, they understood and so the others behind me would call me over to sort something out as well...”

Still, some arrogant shouts over the workers (which I witnessed) were much more in evidence when the boss was around and were usually directed at the youngest and least qualified workers, specially the young women. Resistance varied according to individual cases and could involve more dramatic reactions or more subtle kinds of games. Uncle António (a 60-year old who worked next to me) would sometimes yell in desperation to the supervisor when the belt was running too fast, but never strait to his face and not when he was nearby: “can't he see he can’t do this? Any minute now, I'm going to walk out of here!!”

Such practices clearly reveal that this is not a working class that accepts exploitation passively, but rather, one that resists it in a subtle manner, trying to preserve and recreate zones of freedom in order to protect their collective dignity, which is constantly being wounded on the shop floor. Although open and organized forms of collective action are few and far between, these guerilla micro-tactics (De Certeau, 1984) illustrate that the emancipatory potentialities are not dead.

Certainly, the difficulties of organization and struggle currently faced by the trade union movement in general are also present in this region. But the specificities of this case set it apart from other industrial contexts where political conditions were particularly favourable to radical struggles in the 1970s (as, for instance, in the industrial belts of Lisbon and Setúbal). However, exactly because in this region workers were never familiarized with those experiences, that is to say, exactly because in this case the trade union had to deal with structurally adverse conditions in the past, it had an opportunity to accumulate a huge experience in terms of organizational work in order to reinvent its intervention forms, and this can be considered an advantage. Portuguese

"Demonstration of Clark's workers attracts far less support than in Arouca - To say that there is no work is a bluff" (Comércio do Porto, 4/3/01). 
trade unionism as a whole benefited from the revolutionary climate and class language that became widespread in Portuguese society after the $25^{\text {th }}$ of April (Estanque, 1999), but now most of the union structures are still tied to a traditional model of action and that is why they have greater difficulties in dealing with the current crisis. In the case of the footwear sector, and particularly in SJM and in other regions of diffuse industrialization, the atmosphere of claims-making had little penetration. The instability, mobility and dispersion of the productive process, and the reserve and distrust of a semi-rural work force have meant that trade unions have always had to resort to different strategies. ${ }^{13}$ The fact of the matter is that many of the problems that have always existed in the region prevail, at present, in traditional industrial environments, where, in recent decades, multiple processes of industrial privatization and industrial reconversion have occurred (Lima et al., 1992; Rosa, 1998).

This explains the fine sensitivity regarding the new challenges of trade union action in a context like this. It also explains the refusal to resort to big "demagogic" speeches in a sector characterized by a low-skilled and poorly educated work force.

The problem is this: if you begin to speak about things too much, you end up alienating people. If you are too demagogic about it, it doesn't work. So, people, the leaders, have to see the level of the workers. They have to see that the workers of a footwear factory are not on the same level as an activist or trade union leader. They have very little education and I understand this. It is often difficult for me to make that kind of speech. I prefer more concrete discussions. I've always had this principle, of trying to create a more just society, but speaking about that systematically, and more deeply, is another matter, because I think that this becomes demagogic. (Trade union leader, SJM, July 2000)

These are the problems that oblige trade union leaders to look for new ways of consolidating the levels of implantation already achieved, by developing a critical sense and exposing cases of employer abuse, without losing the practical sense required by socio-economic conditions. While mobilizing workers and contesting undesirable situations, the trade union also supports and participates, for example, in programmes of technological modernization and professional training, developed through company agreements (particularly in the case of large companies) or through the Technological Footwear Centre (whose board of directors includes trade union representatives) in partnership with the entrepreneurial association of the sector (APICCAPS). While

\footnotetext{
${ }^{13}$ One can say that, contrary to former hopes that the gradual development of "consciousness” would result in radical social emancipation, the present scenario reveals that those who were supposed to have achieved such a "consciousness" have been gradually losing it, while those who had never had it, might now promote their own struggle for dignity without paying the cost of disillusionment suffered by those who had assimilated such a utopia.
} 
promoting assemblies and struggles in many companies, it does not neglect cultural activities and relationships with other associations in the community.

This strategy of developing different forms and spheres of intervention has arisen from the need to encourage collective participation in spaces where apathy has prevailed. Intervention in this field may produce a new synthesis based on the split between an industrial activity subjected to rapid and abrupt change, and a community activity which is still sheltered in the profound stagnation of its rural roots.

Many public events throughout the region involving local or national associations can be mentioned to illustrate the dynamics of this trade union ${ }^{14}$. Other initiatives, especially in the field of cultural intervention, have been organized at the headquarters of the footwear workers' union in SJM, most of them taking place in its new Auditorium called José Afonso (the name of a well known left-wing singer of popular ballads), which was inaugurated in 1999. These included recitals, concerts, exhibitions, debates, theatrical performances and book fairs.

This variety of networks and activities clearly shows the importance given to cultural activities, as a fundamental backdrop of trade union strategy. There is an obvious openness to plural languages and forms of intervention and denunciation, which, while preserving a profound belief in the anti-capitalist struggle, also appeals to the need for political alliances outside the trade union field: "at the political level [it is necessary to recover the role of] NGOs, of organizations related to ecology, to the rights of women, minorities, the protection of the poor and homeless... there has to be some connection between these movements, which at present does not exist; they are all dispersed and unconnected...” (Trade Union Leader, June 12, 2000). This orientation, which is far removed from the orthodoxy and dogmatism which undermined the Portuguese trade union movement, points precisely towards a quest for "heterotopias of resistance,” in the sense proposed by Santos (2000: 311). It can be seen as an example of alternative experience that stimulates new coalitions with different actors and movements, overcoming resentment by means of a creative imagination and reinventing

\footnotetext{
14 Associations with which the trade union maintains a regular collaboration, or with which it has established agreements, include: Associação Abril em Maio (a Lisbon cultural association); Associação Recreativa e Cultural de Arouca (a recreational and cultural association); O Sítio - Associação de Jovens "Ecos Urbanos,” of S. João da Madeira (a youth association); the Academy of Music of São João da Madeira; SOS-Racismo and Olho Vivo - Associação Anti-Racismo (anti-racist associations); APCC Associação de Apoio às Crianças Carenciadas (an association for the support of children in need); Escola de Bailado e Artes Cénicas, Vila da Feira (a ballet and theatre school); IGRECA - Grupo de Estudo do Trabalho ao Domicílio (a study group for home-based work); Centro de Documentação 25 de Abril (a documentation centre); and Mutualidades - Associação Cultural, Esmoriz/ Ovar (a cultural association).
} 
new paths for trade unionism towards emancipation. Only under these conditions is it possible to identify social arenas where actors are not limited to accepting submission and exploitation, but where they may tackle the system through innovative forms of resistance.

Undoubtedly there are many obstacles confronting the trade union in this kind of grassroots work, and it is difficult to predict a scenario of generalized emancipatory struggles. But, as we know, the new movements, which are today perhaps more active and efficient in the promotion of collective emancipatory action, operate by opposing the connections of hegemonic domination with new anti-hegemonic connections of resistance - between exploitation and exclusion, the economy and culture, the factory and the community, the local and the global.

\section{Between the local and the global}

The footwear sector has become one of the most dynamic within Portuguese industry in recent decades and this dynamism is largely due to its vocation for exports. ${ }^{15}$ However, we should begin by pointing out that this orientation towards international markets is far from being a recent trend; on the contrary, it has been present throughout the development of the sector since its first steps towards mechanization and modernization in the early decades of the $20^{\text {th }}$ century. Besides, it is this traditional connection to international economic transactions that justifies this line of analysis. The aim is, on the one hand, to understand the way in which local and global dynamics have interacted in the production of adaptive regulatory mechanisms (of the global upon the local), and, on the other hand, to identify and analyse the most recent experiments originating in the community, particularly those which have been activated by means of

\footnotetext{
${ }^{15}$ Production in 1994 was estimated at 330 billion escudos, which represents an average annual growth of 28\%. Exports, which make up approximately $80 \%$ of the national production of the sector, in 1995 showed a growth rate of $35 \%$ over the previous twenty years, which represents, for the same year, $8.1 \%$ of total exports of the Portuguese manufacturing industry (in 1973 it was no more than 1.2\%). In 1974 footwear exports were 3.6 million pairs (555 thousand million escudos), while in 1995 the figure had risen to 76 million pairs (corresponding to 235 billion escudos). As for the volume of employment, the sector grew by 7\% per year in the same period, absorbing in 1997 approximately 72,000 workers. More recent data show that, between 1995 and 2000, national production of footwear continued to grow faster than that of European partners, with a growth rate of $7.7 \%$ in the last five years, reaching the export of 87.5 million pairs in 2000. The latest data reveal a clear recovery of the sector in relation to Italy, the main international producer. In commercial transactions with neighbouring Spain, the trend in the last 5 years has been in favour of Portugal, with exports increasing 514\% throughout the period (SOURCES: $A$ Indústria Portuguesa de Calçado. Edition APICCAPS, Oporto, 1997; INOFOR - Evolução das Qualificações e Diagnóstico das Necessidades de Formação, Sector Report on Tanning, Footwear and Other Leather Products, 2001; APICCAPS, Plano Estratégico para os Próximos cinco Anos, in the newspaper Expresso, June 16, 2001).
} 
trade union action, in order to bring together local resistance and global action and direct them towards an anti-hegemonic and cosmopolitan perspective.

As mentioned above, modern industry in this region, and the footwear industry in particular, was initially launched with the support of capital accumulated by the generation of local emigrants who had made their fortune in Brazil. ${ }^{16}$ Many of these figures today are commemorated in the street names of the city of SJM, in recognition of their important role in promoting local development since the first decades of the $20^{\text {th }}$ century.

Their considerable investments in industrial development and their contributions to the creation of different infrastructures followed a strategy that fed a philanthropic discourse and helped to legitimize the leading role that some of these personalities were to assume in local politics. If it is true that their apparent voluntarism would probably not have been successful if market dynamics had not already begun to make their mark upon the economic activity in the region, it can also be argued that these early industrialists made an important contribution to the transformation of traditional rural communities by bringing them closer to industry. In addition to the fact that the intensification of national and regional commercial relations was a decisive factor for industrial development, this was also strongly mediated by the transnational circulation of capitals, which means that, in that period, global economic transactions profoundly marked local processes. It may also be added that the very process of mobility (the departure and return of emigrants), which made this social sector a pivot of modernization, contains a contradictory logic of de-territorialisation/re-territorialisation, which is inscribed in the identities of the communities and in their adaptation to a regulation subordinated to the demands of capitalist accumulation.

Another dimension that testifies to the way in which the local impact of industrial expansion has always been combined with global factors can be found in the export of footwear. The first industrialists of the sector, many of whom had developed businesses in Brazil, as we have seen, sought to consolidate that market as a privileged destination for their products. But most of the Portuguese footwear manufactured in this region was destined for the Portuguese army, for use by troops taking part in World

${ }^{16}$ As some studies have noted, the experience of migration tends to result in a "border discourse" which shapes the emigrant's "multiplicity of identity" (Capinha, 1997). In this case, it could be said that this multiplicity resulted in a reinforcement of the identification with the community of origin; that is to say, the transnational experience found in mobility a factor for the consolidation of local identity (the strength 
War I. Although this was not exactly export, it obviously responded to demands of a global nature that concerned a geo-political context which, beyond its dramatic consequences, had widespread local repercussions. This was not only because it promoted the first mechanical units of the sector, but also because it indirectly led to the development of several small businesses that began their operations as subcontractors.

This situation, although arising from a particular context, structured local industrial activity and its impact upon the communities. While enabling the sector to gradually orient itself towards export, it also laid the foundations for the increasing vulnerability of the working class and the industry in general to international oscillations in the political and economic scene. More and more sectors of the traditional agricultural workforce were gradually absorbed, which led to the emergence of a highly exploited semi-proletariat, which was docile and dependent, and which saw the factory as an attractive alternative or complement to their traditional means of subsistence. Precisely because the exports of Portuguese footwear to Europe increased significantly throughout the 1930s and 1940s, the economic recession and contraction of the markets brought about by war and social and political upheaval had repercussions on the local level, in the form of the closure of many companies and waves of hunger, disease and misery for the working class of the region (as happened during the Spanish Civil War and particularly during World War II).

The devastating consequences of international crisis in this region clearly illustrate the interdependence that had gradually been established between the global markets and the wage relation in the sector. Despite the restrictive, repressive and nationalist policies of the Salazar regime, the footwear industry managed to keep a window of internationalization open. ${ }^{17}$ The segments of the world market that had been conquered by the sector were naturally continued in the post-war period of international growth and stability.

After the 1950s, and particularly throughout the 1960s, footwear exports expanded substantially, managing to penetrate the American market and countries of the Soviet bloc, while still keeping commercial links with Western Europe, the African colonies and Brazil. However, the international division of labour, despite these ties of

of roots), demonstrating how connections between the global and the local may relegate the national to second rank (Feldman-Bianco, 1993).

${ }^{17}$ I will refer below to some of the local effects of the policies of the so-called Estado Novo, and the way in which, by means of a narrow discourse of local interests and "reactionary progressivism," the local 
interdependence, gradually gave rise to systems of production and experiments in trade union action that were widely divergent. And these past experiences have repercussions in the present. Whereas, in the countries and regions in which the labour movement and industrial systems experienced "fordism," the old model of trade unionism is now desperate to develop strategies adequate to deal with the current global trends of labour fragmentation and crisis in union mobilization, one can say that, in this region, from the 1960s, despite the policies of the Salazar regime, there was a direct entrance into a "post-fordist" phase without having ever passed through "fordism." However, the profound imbalances, socio-cultural divisions and identity recompositions that these changes brought about, can become a potential advantage to the renovation of trade unionism, and through it, for the revival of the principle of community. ${ }^{18}$

Although the discourse that produced the "adapted community" of SJM in the first decades of the $20^{\text {th }}$ century was centred on the articulations between the local and the national, it also brought representations concerning a subjective sense of universalization into which the local/global binomial was inscribed. The first local movements, set in motion by the important personalities and "nouveaux riches" of the region in an attempt to achieve the classification of town and municipality for SJM, ${ }^{19}$ were accompanied by a discourse that glorified the "spirit of sacrifice" and dedication to work carried out in the name of "progress" and industrial modernization. The new status of the town was now displayed upon the map of Portugal no doubt resulted from deliberate attempts to give it greater visibility. But, as we know, the important role played by the dominant classes should not be confused with the emancipation of the people. It may have been an important achievement for the local elites, but perhaps its greatest significance lay in the way it reinforced top-down regulatory mechanisms as regards their relations with the working classes, rather than in the assertion of a type of "bottom-up" power in their relations with the official power structure. A reflex of this is

subjectivities evolved towards a community subjected to official ideology, which mediated between the local and the global.

${ }^{18}$ It is appropriate to recall my initial statements about the "community," which is not taken here as something substantive; rather, the "realization of community means, in this sense, the presence of discursive formulas or processes under construction which aspire to achieve a new collective identity" (Estanque, 2000: 56). If the "fortress communities" of small tradition have been destroyed and if the deterritorialization of the community has produced more "amoeba communities," then these may develop either according to a logic of adaptation, bound by roots, "localized" and of "descent," or according to a logic of emancipation, oriented by a sense of mission, of "ascent" and in search of "cosmopolitanism" (Santos, 1995b; Morris, 1996; Bellah, 1997). In a certain way, the construction of the local community faced this type of contradictory tendencies.

${ }^{19}$ SJM became a town in 1924 and a municipality (concelho) two years later (see Estanque, 2000: 147). 
the fact that this kind of discourse, which was essentially parochial, soon started to become confused with the nationalist doctrine that was then emerging; both had paternalistic contours, and functioned as an ideological support to the Salazar regime and as a fundamental link between disciplinary policies and local powers. It had a considerable impact on the framing of communities, in the spheres of both labour and recreation, namely through the local application of the famous Fascist formula, cynically called “Joy at Work.,"20

From the viewpoint of state action, this was a doctrinal and repressive measure, which sought, like the Nazi experiment, to convert the myth of the old medieval-type community into a new "aestheticized" "folk" community at the service of the Salazar regime. But from the perspective of local dynamics already in operation, it is important to note that this kind of "reactionary modernism" creates a fictitious community, adapted and regulated from within. That is to say, it emanates from the "hard core" of established local power, and responds in large measure to the expansion needs of local industry based upon the fabrication of a new disciplinary logic, of mechanisms of consent, which resulted in the subjugation of the working class and in the "localization" or "colonization" of the community, not only by the national state, but also in response to wider economic connections subjected to the principle of the market and to the export strategy of the local footwear industry.

Although, as I have pointed out, the local impacts of globalization have been felt for some time, the new global liberalism of recent decades has also had visible consequences in this region. These are part of the general logic of exponential growth of central economies, and naturally result in the domination of more fragile economies, namely those situated on the periphery of the world system. If Portugal reflects the contradictions inherent in a semiperipheral society integrated within a central bloc (the European Union), some productive sectors within it (such as this example of the footwear industry) show those contradictions particularly sharply. While exports in the sector continue to account for more than $80 \%$ of production, external investment, which, especially since the 1960s, has been benefiting from the low cost of labour, has in the last decade shifted to the countries of the South, particularly to Asia, for exactly the same reasons. Competition from those countries has had repercussions in Portugal,

\footnotetext{
${ }^{20}$ I am referring here to the main organization for the workers' leisure time, established by the Salazar State in 1935 and inspired by similar experiments by Hitler's and Mussolini's regimes, the so-called National Foundation for Joy at Work (Fundação Nacional para a Alegria no Trabalho or FNAT) (see Rosas, 1992).
} 
resulting in many cases of company relocation, abrupt closure and fraudulent bankruptcies.

Although the footwear sector as a whole has continued to resist the new conditions of global competition, salaries account for only $17 \%$ of production costs, which reflects the fact that it continues to be largely labour intensive, with the average salary of the sector around 375,00 $€$ (euros) per month. The heterogeneous nature of the entrepreneurial fabric continues to nourish deep divisions and interdependencies between the large innovative companies and the vast majority of small units whose subsistence depends on the larger ones, operating according to a system of subcontracting, which encourages home-based labour and illegal production (including even child labour), etc. While there are signs that some producers are beginning to invest in technological reconversion, design and differentiated competitiveness based on quality, many companies, including the most modern, produce mostly for international, European and American brands, which distribute Portuguese products worldwide through large commercial chains and distribution depots, where the label 'made in' disappears. The owners of the major brands, namely English and Scandinavian, have developed franchising contracts with extraordinary marketing gains, selling products that have been manufactured wherever it is most convenient (INOFOR, 2001) and conquering vast segments of the global markets through their logos and images, without the place of origin or manufacturers' names ever being known. We are thus confronted with a strategy of global marketing which is inserted into the primacy of cyberspace over geography, the primacy of global networks over the classical concepts of exchange and market. This is a similar strategy to that of the prestigious brand Nike, which, as Jeremy Rifkin says, "has no productive capital: its shoes are made through anonymous contractors in Southeast Asia - it is an operational cost. The brand's customers pay the price of entering into its legend” (Rifkin, 2001: 18).

It could be argued that, in this case, the "globalized localisms" are not exactly "localisms" but rather diffuse and complex processes that enable transnational capital to perfect mechanisms for the "draining" of resources, thus exponentially increasing their domination and accumulation of wealth. As a result of this, the country or place of production is completely erased, and millions of workers are silently excluded, in a process in which "living work" disappears and what remains is the aesthetic hyperrealism of a product adorned with the colours of the "global" middle class. It could be said that "localized globalisms" correspond in this case to the local impact of economic 
power on these workers and their communities, some of whom are cumulatively exploited in their work, others silenced and relegated to the margins of society and of the system. The hegemonic globalization of the last decade has merely accentuated and rendered more complex the whole web of interdependencies; the intensity of exploitation is now protected by subtler forms of power, better hidden forms of oppression and more sophisticated forms of domination, which are reproduced in a chain from the international centres of economic power to the domestic sphere of the poorest worker. It is in this sense that the subordination of communities to industry follows the same logic of the "colonization" of the local by the global, that is, the domination of workers' collectivities and their community and family ways of life by the power of global capital. For this reason, it makes sense, in my opinion, to interpret the problems and potentialities of the trade union's new strategies of internationalization through solidarity as a counterpart to the powerful impact of the global markets upon the region and the working classes, as we have seen.

\section{Towards a new global and anti-hegemonic labour internationalism}

As we know, the crisis in the trade union movement has become more accentuated over the last two decades (Hyman, 1994). After a phase of relative euphoria during the 1960s and 1970s, statistics show an ebb between 1980 and 1990. According to OECD data, there was a drop during this period in all member countries of approximately 7\% of wage workers (OECD, 1991). From 1974 to 1995, membership rates in Portugal decreased from 52\% to 30\% (Cerdeira, 1997: 51). The reduction in union membership is combined with models of competitive union pluralism, which contributes to weakening the unions' negotiating power (Ferreira, 2001: 270-277). In the footwear union, this trend towards increased disaffiliation can also be seen. While at the beginning of the 1990s the membership rate was close to 55\% (a figure much above the national average at that time), the percentage of members is today nearer $35 \%$, according to the most recent information from the union.

Nevertheless, while it is clearly true that labour is today more divided and precarious, and capital more united and coordinated on the global level, it does not necessarily follow that, as Castells argues (1996: 360), the “workers' movement was historically suppressed," or that it has even lost its capacity to transform and emancipate (Waterman, 1999). It is true that traditional trade unionism seems to be collapsing, but 
there is also evidence that it may be possible to revive it, although under new bases of intervention.

For example, the European experiment of implementation of European Works Councils (EWCs), although limited to large companies and subject to many difficulties, demonstrates a potential that constitutes a challenge for Portuguese workers and Portuguese trade unionism, with possible emancipatory consequences (Costa, 2000); and the trade union network SIGTUR, ${ }^{21}$ studied by Lambert and Webster (2000), clearly illustrates the virtues of an anti-hegemonic global social movement, based on a new labour internationalism which tries to combine traditional trade union organization with modern information networks.

Similarly, the case analysed here also shows innovative potential in this area. I have already shown how the footwear workers' union has made a mark on the region, not only through its exposure of abused rights and the unbridled exploitation of workers, but also as a decisive pivot of solidarity and dynamics of the many association initiatives in the sphere of the community. Following the line of analysis I have been developing, it is important to stress the efforts that the footwear workers' union has been making to counteract the destructive effects of neoliberal globalization through innovative forms of counterhegemonic globalization, which seek to converge with new global movements of resistance through participation in international networks of collective mobilization.

Throughout the 1990s, the trade union began to extend its local coalitions to a global scale, involving the participation of different actors and plural forms of intervention. This was what happened when, in 1997, the trade union leadership joined the project of the European Marches against Unemployment and Precariousness ${ }^{22}$, besides the main co-federation CGTP-IN ${ }^{23}$ only joined the movement later. This intervention in international networks (mainly in Europe but also extending to Brazil) clearly illustrates the importance attributed both to the institutional framework of labour policies within the European Union, and to initiatives promoted by trade union

\footnotetext{
${ }^{21}$ Southern Iniciative on Globalization and Trade Union Rights.

${ }^{22}$ Participating in demonstrations such as Brussels, April 1997; the Zurich-Marseilles march, May 1997; Oporto, January 2000; and in Nice, December 2000.

${ }^{23}$ The footwear trade union of S. João da Madeira is affiliated to the General Confederation of Portuguese Workers [CGTP-IN], but it has maintained an independent position in relation to the hegemonic current of its directorate, politically closer to the Portuguese Communist Party. The other large federation rivaling this one (the General Union of Workers/UGT) takes a more reformist and moderate stance, and supports negotiation and social "concertation" rather than mass mobilization; it is politically aligned with the Socialist Party.
} 
organizations on the transnational level. Such an intervention is thus reflected at the level of dialogue and negotiation mechanisms, as well as in protest demonstrations. For example, as regards the EU directive on the European Works Councils (EWCs), the trade union was represented in different meetings dealing with the application of the directive in multinational companies of the sector established in the region (such as the firms Ecco Let, C. \& J. Clark, and Rhode), and followed these proceedings closely. In particular, it exposed attempts to manipulate the respective electoral acts designed to elect workers' representatives in the EWCs, ${ }^{24}$ and, as a result, those illegal acts were annulled. It is this type of intervention that reinforces the mediating role of the trade union in negotiating processes, and strengthens its international position among similar unions in Europe.

In addition, it has forged closer connections with the Brazilian trade union movement, maintaining contacts with the federation $\mathrm{CUT}^{25}$ and with the Shoemakers Union of Nova Amburgo, and participating in December 1999 in various trade union meetings in Rio Grande do Sul. Following a similar course of action to the current global social movements, the leaders of the SJM footwear workers' union are making increasing use of cyber networks on the worldwide web for access to up-to-date information, which they then divulge to their members and to the local population. Thus, they seek to show how local problems frequently originate in global factors, thereby stimulating sentiments of solidarity with the victims of hegemonic globalization worldwide. Various international associations and movements are on the list of partners and agreements that have been made in recent years.

MST - Movimento dos Sem Terra (Landless Workers Movement) Brazil;

CUT - Central Única dos Trabalhadores (Unified Workers Confederation) Brazil;

VIENTO SUR - Journal of Economic and Social Affairs, Brazil;

MOUVEMENT DES “SANS PAPIERS” (Movement of illegal immigrants), France;

AGIR CONTRE LE CHÔMAGE (Movement against unemployment), France;

PLATAFORMA 0,7 - Madrid;

CGT - CONFEDERACIÓN GENERAL DEL TRABAJO (General Confederation of Labour) Madrid;

DERECHOS PARA TOD@S, (Rights for All), Madrid;

PAZ AHORA (Peace Now), Madrid;

EUROPEAN HOMEWORKING GROUP, Leeds, England;

COMISSIÓN OBRERA NACIONAL DE CATALUNHA, (National Committee of Workers of Catalonia), Barcelona;

OIBRÍ BAILE (Group for home-based labour), Ireland;

${ }^{24}$ See the case of the annulment of an agreement with the headquarters of Ecco Let in Denmark, which had been signed by delegates "nominated" by the management instead of democratically elected by their peers, as mentioned by Hermes Costa (2000).

${ }^{25}$ Unified Workers Confederation/ Brazil. 
MAQUILA SOLIDARITY NETWORK (Group for home-based labour), Toronto; HOMENET (Groups for home-based labour), India, Thailand, Santiago do Chile; OUTWORK TCFUA (Group for home-based labour), Carlon, Australia; (SOURCE: Trade Union of Workers in Footwear, Bags and Related Articles of the Districts of Aveiro and Coimbra)

Many of these organizations have joined in different demonstrations and collective protests (such as the previously mentioned European Marches), and, like the trade union analysed here, have a place within the broader movement of peaceful protest against hegemonic globalization ${ }^{26}$. This intervention effort, which oscillates between the local and the global and which seeks to connect both types of logic within the same process, may be read not only according to the old ecological motto "think globally, act locally," but also as an attempt to reinterpret the notion in a way which is perhaps more suitable to the current context — "think locally, act globally.” This perspective rests, then, on the idea that thought and action have today more possibilities than ever of crossing borders and dialectically producing solutions for current problems, either by discovering alternatives for local questions on the basis of global action, or by contributing to a new universal humanism of solidarity based on local action. Thus, one might say that, when the reality of SJM footwear workers is exposed in international forums, it is not only the world of industrial production that is put into question, but the whole local context surrounding this reality.

The emancipatory orientation that has been followed is based, therefore, not only upon the construction of platforms and local alliances, but also upon expansion to the global level of intervention; and this has been the strategy underlying the actions of this union and its leadership over the last decade. In other words, it is a strategy that brings together the concerns of both the "old” and new types of internationalism, conveying a labour solidarity of the "revolutionary" type and also a sentiment drawn from experiences that are not restricted to union militancy. It is useful to bear in mind here that the principal leader of the union was in the past very active in party politics and associations, combining cultural intervention (mentioned in the previous section) and membership of parties of the extreme left (of Trotskyist inspiration, such as the LCI and PSR), not to mention an identification with grassroots union currents (such as

\footnotetext{
${ }^{26}$ Besides the controversies raised by these protest movements - in Seattle, Genoa, Melbourne, Prague, Davos, Gothenburg, etc. - , particularly due to the violence and the perverse effects of media coverage, it is important to stress that the large majority of activists and NGOs involved in those actions are motivated by solidarity, and consider themselves to be pacifists, seeking to influence political agendas and alert world public opinion to some of the serious social problems (environment, human rights, war, etc.) which plague the world today.
} 
BASE-FUT). It is not surprising, therefore, that his stance combines a "culturalist” and "grassroots" vocation with a great openness vis-à-vis current movements of global solidarity. This is evident in his discourse, which contains both a radical critique of capitalist globalization and the profound conviction that nothing is achieved without the hard work of organization and mobilization. It is thus a discourse that basically links an updated and open form of ideological radicalism with a pragmatic sense of immediate action.

There is a need to create alternatives to this system. If we take ecologist measures to their extreme, it is clear that the movement has to be anti-capitalist, in the strict sense of capitalism, as a system existing only for accumulation and not serving human beings. Because today, with the present state of knowledge and technology, human beings are on a level where there is no need for so much poverty... But the system is made to create this poverty and this wealth (...)

Nothing can be done without the work of organization (...) So, there has to be an articulation between these movements, both in Portugal and internationally. That is to say, nothing will happen if great efforts are not made to mobilize, organize, reflect, so that everyone together manages to put a spoke in the works, try to create stronger and more powerful movements in Portugal and in Europe and worldwide. There are millions of people in the world who are acting now! They are acting, like that peasant leader in France who recently invaded MacDonald's. That was not banditry, it was an act against this system of normalization and globalization, which bars everyone, fires everyone, makes everyone unemployed, and is in favour of large economic groups and the brutal accumulation of great fortunes, isn't it? That action provoked sympathy in millions of people, and now what is necessary is to articulate those forces in all areas. (Union leader, SJM, July 2000)

In this vision, what stands out is clearly the importance given to the counterhegemonic movements appearing in the world today, together with the need to articulate the trade union movement with other movements, local and national problems with the global logic. In addition, we also get a clear idea that current social and cultural movements are scattered, and that a great effort will be needed to articulate the different fields of collective action, otherwise trade unions will have difficulty in finding alternative routes to a more just and solidary society.

As this conception is, in the end, the product of the cultural and socio-economic reality of the region, it cannot but be taken as an example that provides empirical proof of the arguments developed throughout this chapter. The local framework that, over the years, was an important mainstay of regulatory normalization, also produced underground sites of contestation and dissident voices. Although these may be no more than the expression of an emancipation that has been subjugated and absorbed by regulation (Santos, 2000:335), they have a tendency to persist as silent germs of latent resistance. Born in the silence of the margins, the voice of the trade union finds an echo 
in the hidden vibrations of the "localized" community in order to become a great resonating sound in the centres of "cosmopolitan" contestation. In this sense, cosmopolitanism is no more than another name for universalized localism.

\section{Conclusion}

The growing fragmentation and weakening of labour and of the traditional union movement is bringing to the fore the need to study the new challenges that this field has been facing, as well as the urgent need to find alternative ways to revitalize and reinvent it. A critical analysis that is also politically committed cannot limit itself to the underlining of difficulties and the dramatization of situations that are already dramatic. It also cannot override reality and invent something that does not exist. But it can, and to my mind should, if it wishes to remain faithful to the critical theory that provided the main analytical support to this collective project, reveal the other side of what exists but does not let itself be seen, making visible both the human dramas hidden under the mantle of multiple oppressions and the experiences, struggles and initiatives which, by their exemplary nature, can open up new paths to emancipation and contribute to the strengthening of the new humanist forms of internationalism based upon solidarity that have emerged in the last decade.

In this chapter, I have analysed a case in which old and new forms of oppression, exploitation and exclusion are clearly inscribed within the logic of global economic domination. I have sought to understand them on the basis of the historical and socio-cultural factors that accompanied the industrial development of the region from the beginning of the $20^{\text {th }}$ century, showing their power and ability to frame industrial production in local communities, and also the way in which this framework obeyed the economicist dictates of the markets and was influenced by international political conjunctures. Despite the efficacy with which these factors managed to connect transnational structures of economic power to mechanisms of local control, and notwithstanding the regulatory force of the local capitalist elite and its triumph over class-based practices and struggles and community rebellion, the exercise of this economic, social and symbolic power has always been opposed by forces of rebellion and resistance arising from the grassroots.

The way in which the principle of the market has imposed itself upon the principle of community has exposed the contradictions of the former and the creativity of the latter. While the adaptation of the community had to be accompanied by 
solidarity initiatives controlled by industrialists, the hegemony of the market had to be supported by state action (notably the repressive authoritarianism used by the Salazar regime) in order to manufacture the sort of consent that suited its designs. At the same time, the local impacts of different global mechanisms translated themselves into factors of oppressive regulatory pressure, which, from the 1980s, were greatly reinforced. This is an alarming trend, which has given rise to new union policies as regards alliances, and a reorientation of its intervention towards the transnational level in an attempt to oppose the localism of exclusion with a globalist, inclusive and cosmopolitan approach, which tries to overcome local oppression through global solidarity.

Community recomposition has also been affected by contradictory influences over the years, which have sometimes opened up the way for initiatives of resistance and acts of rebellion. It was indeed in the gaps between these contradictions that union action has intruded in order to promote labour struggles. However, confronted with forms of regulation that evolved from old patriarchal allegiances into modern employer despotism, workers rarely supported union initiatives that were limited to the world of production. This is why the union (despite its important victories during the eighties in struggles against arbitrary violence from entrepreneurs, discrimination against women and child labour) began to move increasingly in the sphere of associationalism and cultural work in the community as a way of reinforcing its capacity to intervene on behalf of workers. Although this opening-up of horizons has not yet yielded great results in mobilization, it clearly illustrates the imaginative potential and heterodox creativity of a leadership able to ally the everyday issues of labour and proximity with workers both inside and outside the companies with a great sensitivity towards cultural intervention in collectivities and associations in the region. It is a strategy which not only offers resistance to unsociable and individualist indifference but also promotes emancipation in the community by building new alliances and bringing together the most precarious and vulnerable segments of the workforce (such as the unemployed, the aged, young people and women working at home, etc.).

This strategy of multiple intervention contributes to the strengthening of conditions and programmes of negotiation which the union pursues in other ways (through dialogue with employers, the state and other social partners), revealing how the paradigmatic struggle operates both from within and without, gathering strength on the margins in order to undermine the centres of power within the mechanisms of regulation themselves. Furthermore, this orientation also promotes the articulation 
between labour action and different social and cultural movements. Indeed, this is one of the paths generally indicated for the revitalization of unionism. However, if this type of response reveals creative potential for the reinvention of union action, it can still be complemented by other forms of participation, namely at the transnational and global level.

Therefore, the internationalist praxis of this union, in assuming a greater role in struggles against neoliberal hegemonic globalization alongside other types of activism and other social movements, is guided by a course of action aimed at counteracting and resisting the destructive effects of the multinational companies in the sector, while seeking to invert the process of "oppressive localization” which has maintained labour collectivities and their communities subjected to "conformist sociabilities"; it seeks to orient its action in an anti-hegemonic direction, thus contributing to a new visibility of workers' problems and a reinforcement of new dimensions and networks of international solidarity. Well ahead of most Portuguese unions, the SJM footwear workers' union and its leadership have revealed an imaginativeness and a potential that justify it being placed on the front line of present-day internationalist emancipatory movements.

Thus, we may conclude by saying that this union’s struggle for emancipation clearly illustrates the potential hidden behind the logic of regulation which developed over the years out of the hegemonic forces that subjected the community to industry, and the local to the global. By seeking to rejoin what has been separated, it hopes to restore the dignity of labour through community intervention, and to promote the emancipation of the local by intervening in the global counterhegemonic networks, struggles and social movements. 


\section{Bibliography}

Ashwin, Sarah (2000), "International Labour Solidarity After the Cold War," in Robin Cohen and Shirin Rai (eds.), Global Social Movements. London: Athlone, 101116.

Bellah, Robert (1997), “The Necessity of Opportunity and Community in a Good Society,” International Sociology, vol. 12(4), 387-393.

Bezuidenhout, Andries (1999), "Towards Global Social Movement Unionism? Trade Union Responses to Globalization in South Africa.” Geneva: International Labour Organisation (www.ilo.org/public/english/bureauc/inst/papers/2000/dp115/), accessed on 11.07.2001.

Burawoy, Michael (1985), The Politics of Production. London: Verso.

Cabral, Manuel Villaverde (1979), Portugal na Alvorada do Século XX. Lisbon: A Regra do Jogo.

Capinha, Graça (1997), "Ficções credíveis no campo da(s) identidade(s): a poesia dos emigrantes portugueses no Brasil,” Revista Crítica de Ciências Sociais, 48, 103-146.

Castells, Manuel (1998), End of Millenium. The Information Age: Economy, Society and Culture (Vol. III). Oxford: Blackwell.

Cerdeira, Maria da Conceição (1997), “A sindicalização portuguesa de 1974 a 1995,” Sociedade e Trabalho, Ministério para a Qualificação e o Emprego, 1, 46-53.

Costa, Hermes Augusto (2000), “O Sindicalismo Português face aos Conselhos de Empresa Europeus.” Paper presented to the International Symposium Reinventing Social Emancipation. University of Coimbra, November 2000.

De Certeau, Michel (1984), The Practice of Everyday Life. Berkeley: University of California Press.

Estanque, Elísio (1999), “Acção colectiva, comunidade e movimentos sociais: para um estudo dos movimentos de protesto público,” Revista Crítica de Ciências Sociais, 55, 85-111.

Estanque, Elísio (2000), Entre a Fábrica e a Comunidade: subjectividades $e$ práticas de classe no operariado do calçado. Oporto: Afrontamento.

Featherstone, Mike et al. (1995), Global Modernities. London: Sage.

Feldman-Bianco, Bela (1993), "Múltiplas camadas de tempo e espaço: (re)construções da classe, da etnicidade e do nacionalismo entre imigrantes portugueses,” Revista Crítica de Ciências Sociais, 38, 193-223.

Ferreira, António Casimiro (2001), "Para uma concepção decente e democrática do trabalho e dos seus direitos: (re)pensar o direito das relações laborais,” in Santos, Boaventura de Sousa (ed.), Globalização: Fatalidade ou Utopia?. Oporto: Afrontamento, 259-296.

Gentili, Pablo (org.) (1999), Globalização Excludente: Desigualdade, Exclusão e Democracia na Nova Ordem Mundial. Petrópolis: Editora Vozes.

Giddens, Anthony (1990), The Consequences of Modernity. Stanford: Stanford University Press. 
Habermas, Jürgen (1989), The Theory of Communicative Action: Lifeworld and System. A Critique of Funcionalist Reason. Cambridge: Polity Press.

Habermas, Jürgen (1998), O Discurso Filosófico da Modernidade. Lisbon: Publicações Dom Quixote.

Held, David and McGrew, Anthony (2001), Prós e Contras da Globalização. Rio de Janeiro: Zahar.

Hirst, Paul and Thompson, Grahame (1996), Globalization in Question. Cambridge: Polity Press.

Hobsbawm, Eric J. (1984), Worlds of Labour: Further Studies in the History of Labour. London: Weidenfeld.

Hyman, Richard (1994), "Trade Unions and the Disaggregation of the Working Class,” in Marino Regini (ed.), The Labour Movements. London: Sage, 150-168.

INOFOR (2001), Evolução das Qualificações e Diagnóstico das Necessidades de Formação. Sectoral report on tanning, footwear, and other leather products. Lisbon: Ministério do Trabalho e da Solidariedade.

Jones, G. Stedman (1989), Languages of Class - Studies in English Working Class History 1832-1982. Cambridge: Cambridge University Press.

Laclau, Ernesto (1996), Emancipation(s). London: Verso.

Lash, Scott (1999), “Crítica da informação,” Revista Crítica de Ciências Sociais, 54, 13-30.

Lambert, Rob and Webster, Edward (2000), "Social emancipation and the new labor internationalism: a southern perspective." Paper presented to the International Symposium Reinventing Social Emancipation. University of Coimbra, November 2000.

Lima, Marinús Pires de, et al. (1992), A Acção Sindical e o Desenvolvimento. Lisbon: Edições Salamandra.

Linstead, Steve (1985), "Jokers wild: the importance of humor in the maintenance of organizational culture,” The Sociological Review, vol. 33(4), 741-767.

Moody, Kim (1997), Workers in a Lean World: Unions in the International Economy. London: Verso.

Morris, Paul (1996), “Community Beyond Tradition,” in Paul Heelas et al. (eds.), Detraditionalization. Oxford: Blackwell Publishers, 223-249.

O'Hearn, Denis (2000), “Globalization, the 'New Tigers' and the End of the Developmental State? The Case of the Celtic Tiger,” Politics \& Society, 28(1), 67-92.

OECD (1991), Perspectives de L'Emploi. Geneva: OECD.

Pureza, José Manuel (2001), "Para um internacionalismo pós-vestfaliano,” in Santos, Boaventura de Sousa (ed.), Globalização: Fatalidade ou Utopia?. Oporto: Afrontamento, 238-258.

Ray, Larry J. (1993), Rethinking Critical Theory: Emancipation in the Age of Global Social Movements. London: Sage.

Riftin, Jeremy (2001), "Quando os Mercados se Apagam ante as Redes: uma transformação radical do capitalismo," Le Monde Diplomatique - Portuguese edition, Year 3, No. 28, July. 
Rosanvallon, Pierre (1988), La Question Syndicale. Paris: Calmann-Lévy.

Rosa, Maria Teresa Serôdio (1998), Relações de Trabalho e Sindicalismo Operário em Setúbal. Oporto: Afrontamento.

Rosas, Fernando (coord.) (1992), Portugal e o Estado Novo (1930-1960). Lisbon: Editorial Presença.

Santos, Boaventura de Sousa (1994), Pela Mão de Alice - O social e o político na pós-modernidade. Oporto: Afrontamento.

Santos, Boaventura de Sousa (1995a), "Teses para a Reinvenção do Sindicalismo em Portugal, seguidas de um apelo,” Vértice, 68, 132-139.

Santos, Boaventura de Sousa (1995b), Toward a New Common Sense: Law, Science and Politics in the Paradgmatic Transition. London/ New York: Routledge.

Santos, Boaventura de Sousa (2000), A Crítica da Razão Indolente: contra o desperdício da experiência. Oporto: Afrontamento.

Tengarrinha, José (1981), “As greves em Portugal: uma perspectiva histórica do século XVIII a 1920,” Análise Social, 67/68/69, 573-601.

Thompson, E. P. (1987) [1963], A Formação da Classe Operária Inglesa. Rio de Janeiro: Paz e Terra (vols. I, II e III). English edition: The Making of the English Working Class. London: Harmondsworth/Penguin.

Waterman, Peter (2000), “Trade Union Internationalism in the Age of Seattle” (http://www.antenna.nl/ waterman/), accessed on 11.07.2001. 